\title{
Embryonic Immunostaining for the Tardigrade Hypsibius exemplaris
}

\author{
Frank W. Smith ${ }^{1,3}$ and Willow N. Gabriel ${ }^{2}$ \\ ${ }^{1}$ Biology Department, University of North Florida, Jacksonville, Florida 32224; ${ }^{2}$ Department of Biology, University \\ of North Carolina at Chapel Hill, Chapel Hill, North Carolina 27599
}

\begin{abstract}
Immunostaining is a method used to visualize the localization of proteins in fixed tissue. Many antibodies are available that recognize specific proteins in a wide diversity of organisms, which makes this method ideal for investigating gene expression patterns in nonmodel animal systems. This protocol describes immunostaining for studies of embryogenesis in the tardigrade Hypsibius exemplaris.
\end{abstract}

\section{MATERIALS}

It is essential that you consult the appropriate Material Safety Data Sheets and your institution's Environmental Health and Safety Office for proper handling of equipment and hazardous materials used in this protocol.

RECIPES: Please see the end of this protocol for recipes indicated by $<R>$. Additional recipes can be found online at http://cshprotocols.cshlp.org/site/recipes.

Reagents

\section{Antibodies}

A primary antibody and a fluorescently labeled secondary antibody are used in this protocol.

Bovine serum albumin (BSA; $0.2 \%)<\mathrm{R}>$

Chymotrypsin/chitinase solution $<\mathrm{R}>$

Fixative solution for Hypsibius immunostaining $<\mathrm{R}>$

Methanol $(25 \%, 50 \%, 70 \%$, and $90 \%$ [v/v] in $0.5 \times$ PBT; $100 \%)$

Mounting medium with anti-fade reagent (e.g., Fluoromount-G [Invitrogen 00495802])

Normal goat serum (NGS; $5 \%)<\mathrm{R}>$

$\operatorname{PBT}(0.5 \times)<\mathrm{R}>$

Spring water

Use commercial bottled spring water found in grocery stores. Do not use tap water; the chlorine and/or chloramine common in tap water is harmful to many microscopic animals.

Tardigrade (H. exemplaris) maternal exuviae

For general advice on maintaining tardigrades in the laboratory, see Protocol: Laboratory Culture of Hypsibius exemplaris (McNuff 2018).

\footnotetext{
${ }^{3}$ Correspondence: frank.smith@unf.edu

From the Emerging Model Organisms collection.

Supplemental material is available for this article at cshprotocols.cshlp.org.

(C) 2018 Cold Spring Harbor Laboratory Press

Cite this protocol as Cold Spring Harb Protoc; doi:10.1101/pdb.prot102343
} 
F.W. Smith and W.N. Gabriel

Equipment

Collection tubes $(2 \mathrm{~mL})$

Fluorescence microscope

Microcentrifuge

Microcentrifuge tubes ( $1.5 \mathrm{~mL}$, low-retention)

Microscope slides

Mobicols (Boca Scientific)

Mobicol mini-columns with Luer-lock cap, closing cap, and plug (M1002)

Large filters for Mobicols, $10-\mu \mathrm{m}$ pore size (M2210)

Bottom filters for Mobicols, $10-\mu \mathrm{m}$ pore size (M2110)

Needles (25 gauge)

Pasteur pipettes ( 9 inch, glass)

Petri dishes $(35 \mathrm{~mm} \times 10 \mathrm{~mm})$

Syringes $(1 \mathrm{~mL})$

Vortexer (VWR Genie 2 G560)

METHOD

Immunostaining has been successfully implemented for studies of embryogenesis in $\mathrm{H}$. exemplaris (Gabriel and Goldstein 2007; Gross and Mayer 2015). The protocol presented here is based on immunostaining protocols developed for H. exemplaris embryos (Gabriel and Goldstein 2007) and adults (Smith and Jockusch 2014), an in situ hybridization protocol developed for $\mathrm{H}$. exemplaris (Smith et al. 2016), and a method developed to study gene expression in small embryos (Irvine 2007).

Throughout the protocol, make sure that the embryos remain submerged in liquid. Perform all steps at room temperature unless otherwise indicated.

Embryo Collection

1. In a $35 \mathrm{~mm} \times 10 \mathrm{~mm}$ Petri dish filled with spring water, slice through the middle of maternal exuviae filled with embryos with a 25 -gauge needle attached to a sterile 1 -mL syringe (see Supplemental Movie S1).

2. Transfer embryos to a $1.5-\mathrm{mL}$ tube filled with $0.5 \times \mathrm{PBT}$.

We routinely follow this protocol with 20-50 embryos per 1.5- $\mathrm{mL}$ tube.

Primary Permeabilization

3. Centrifuge the $1.5-\mathrm{mL}$ tube containing embryos at $18,500 \mathrm{~g}$ for $3 \mathrm{~min}$.

4. Remove most of the liquid, leaving embryos suspended in $\sim 20 \mu \mathrm{L}$ of $0.5 \times \mathrm{PBT}$.

5. Add $20 \mu \mathrm{L}$ of chymotrypsin/chitinase solution, and let stand for $1 \mathrm{~h}$. Centrifuge at $3000 \mathrm{~g}$ for 3 $\mathrm{min}$, and remove most of the liquid.

6. Wash three times as follows: Add $500 \mu \mathrm{L}$ of $0.5 \times$ PBT, let stand for $5 \mathrm{~min}$, centrifuge at $3000 \mathrm{~g}$ for 3 min, and remove most of the liquid.

Paraformaldehyde Fixation

7. Wash with $1 \mathrm{~mL}$ of fixative solution while shaking vigorously on a VWR Genie 2 G560 Vortexer set to shake speed 3 for $30 \mathrm{~min}$. Centrifuge at $3000 \mathrm{~g}$ for $3 \mathrm{~min}$, and remove most of the liquid.

8. Wash five times as follows: Add $500 \mu \mathrm{L}$ of $0.5 \times \mathrm{PBT}$, let stand for $5 \mathrm{~min}$, centrifuge at $3000 \mathrm{~g}$ for 3 min, and remove most of the liquid. 
Downloaded from http://cshprotocols.cshlp.org/ on April 26, 2023 - Published by

Embryonic Immunostaining of Tardigrades

\section{Cleaning Mobicol Mini-Columns}

9. Set up mini-columns as in Figure $1 \mathrm{~A}$ and B, and then wash them four times as follows:

i. Unscrew the Leur-lock cap, add $600 \mu \mathrm{L}$ of $0.5 \times$ PBT to the top of the mini-column, and then screw the Leur-lock cap and syringe back on.

ii. Push the syringe plunger all the way down, and discard the liquid that collects in the tube.

\section{Methanol Dehydration}

For all mini-column washes below, unscrew the Leur-lock cap, add the liquid to be used for washing the embryos, and then screw the Leur-lock cap and syringe back on. After letting the embryos stand in the liquid for the specified time, push the liquid through the mini-column with a 1-mL syringe (see the black dashed line in Fig. 1A). The embryos must remain submerged in liquid at all times, so during these washes, pull back on the syringe plunger to form a vacuum in the mini-column to ensure that not all of the liquid is lost.

10. Transfer the embryos to a clean mini-column using a 9 inch glass Pasteur pipette.

11. Wash embryos for $5 \mathrm{~min}$ in $500 \mu \mathrm{L}$ of $25 \%$ methanol in $0.5 \times$ PBT.

12. Repeat Step 11 with $50 \%, 70 \%$, and $90 \%$ methanol in $0.5 \times$ PBT.

13. Quickly wash the embryos three times in $500 \mu \mathrm{L}$ of $100 \%$ methanol. After adding the final wash of $100 \%$ methanol, insert a bottom plug into the column and replace the Luer-lock cap with a closing cap (Fig. 1C). Leave the tube at $-20^{\circ} \mathrm{C}$ for at least $20 \mathrm{~min}$.

Methanol Rehydration

14. Remove the bottom plug, and replace the closing cap with the Luer-lock cap and syringe. Wash the embryos for $5 \mathrm{~min}$ each in $500 \mu \mathrm{L}$ of $90 \%, 70 \%, 50 \%$, and $25 \%$ methanol in $0.5 \times \mathrm{PBT}$, followed by three quick washes with $500 \mu \mathrm{L} 0.5 \times$ PBT.
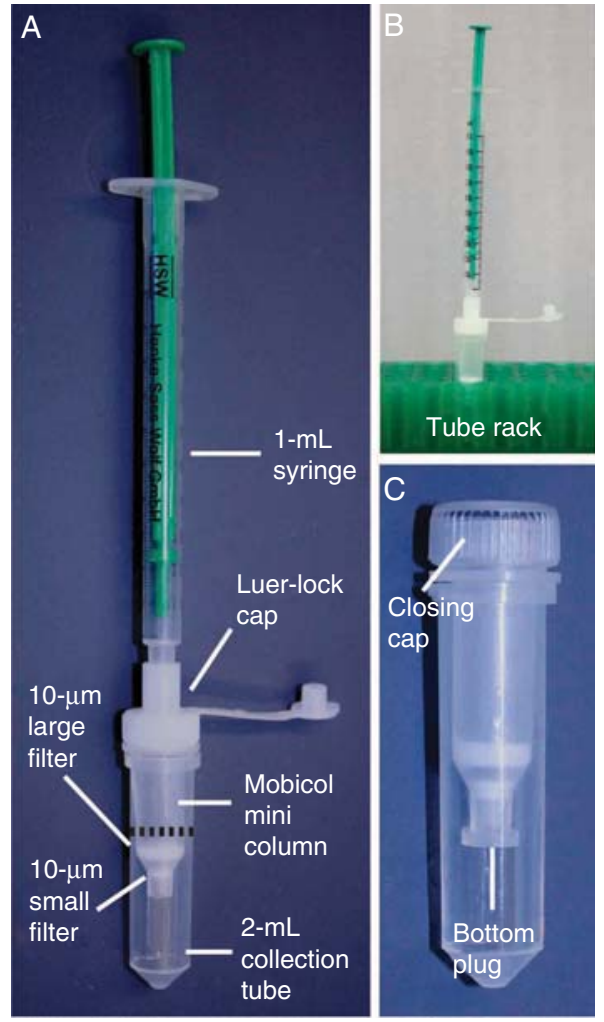

FIGURE 1. (A) The Mobicol mini-column configuration used in this protocol. The black dashed line denotes the approximate level to which we reduce the embryo suspension during wash steps. $(B)$ The mini-columns are kept in a tube rack for this protocol. (C) The minicolumn configuration while the embryos are stored in methanol at $-20^{\circ} \mathrm{C}$. 
F.W. Smith and W.N. Gabriel

\section{Secondary Permeabilization}

15. Use a 9 inch glass Pasteur pipette to transfer the embryos from the mini-column into a $35-\mathrm{mm}$ dish filled halfway with $0.5 \times$ PBT.

16. Cut the embryos out of the eggshells with a 25-gauge needle attached to a 1 -mL syringe (see Supplemental Movie S2).

17. Re-collect the embryos in a clean mini-column in $500 \mu \mathrm{L}$ of $0.5 \times \mathrm{PBT}$, and then push the excess liquid through the mini-column with a $1-\mathrm{mL}$ syringe.

Primary Blocking

18. Wash the embryos three times for $10 \mathrm{~min}$ each and four times for $30 \mathrm{~min}$ each in $500 \mu \mathrm{L}$ of $0.2 \%$ BSA.

19. Wash embryos twice for 30 min each with $500 \mu \mathrm{L}$ of $5 \%$ NGS.

Primary Antibody

20. Add $500 \mu \mathrm{L}$ of primary antibody diluted in $5 \% \mathrm{NGS}$, and leave overnight at $4^{\circ} \mathrm{C}$.

The appropriate primary antibody concentration is antibody specific and needs to be experimentally determined. Typical antibody concentrations used for immunostaining are between 1:100 and 1:1500.

21. Wash three times for 5 min each and four times for 30 min each in $500 \mu \mathrm{L}$ of $0.5 \times$ PBT.

$\stackrel{\infty}{\circ}$ Secondary Blocking

22. Wash two times for $1 / 2 \mathrm{~h}$ each in $500 \mu \mathrm{L}$ of $5 \%$ NGS.

Secondary Antibody

23. Wash overnight with $500 \mu \mathrm{L}$ of fluorescently labeled secondary antibody diluted in $5 \%$ NGS.

The appropriate secondary antibody concentration is antibody specific and needs to be experimentally determined. Typical antibody concentrations used for immunostaining are between 1:100 and 1:1500.

24. Wash three times for 5 min each and six times for 30 min each in $500 \mu \mathrm{L}$ of $0.5 \times$ PBT.

Imaging

25. Mount embryos on microscope slides in Fluoromount-G or other appropriate mounting medium with anti-fade reagent.

26. Image with a fluorescence microscope.

See Troubleshooting.

Problem (Step 26): The signal is low.

Solution: Increase concentration of primary and/or secondary antibodies (Steps 20 and 23).

Problem (Step 26): Background staining is high.

Solution: Decrease concentration of primary and/or secondary antibodies (Steps 20 and 23). Alternatively, decrease incubation times for primary and/or secondary antibodies (Steps 20 and 23). 
Bovine Serum Albumin (BSA; $0.2 \%$ )

$\begin{array}{lr}\text { Bovine serum albumin } & 0.1 \mathrm{~g}\end{array}$

$\operatorname{PBT}(0.5 \times)<\mathrm{R}>$

$49 \mathrm{~mL}$

Final volume

$\sim 50 \mathrm{~mL}$

Store for up to $1 \mathrm{mo}$ at $4^{\circ} \mathrm{C}$.

Chymotrypsin/Chitinase Solution

Chitinase (Sigma-Aldrich C6137)

5 units

Chymotrypsin (Sigma-Aldrich C4129)

$10 \mathrm{mg}$

$0.5 \times$ PBS (diluted from $10 \times$ PBS [pH 7.4] $<\mathrm{R}>$ )

$1 \mathrm{~mL}$

Final volume

$\sim 1 \mathrm{~mL}$

Store for up to $1 \mathrm{mo}$ at $4^{\circ} \mathrm{C}$ in the dark.

Fixative Solution for Hypsibius Immunostaining

Heptane

$333.33 \mu \mathrm{L}$

16\% formaldehyde (Electron Microscopy Sciences 15700)

$250 \mu \mathrm{L}$

Triton X-100 $\left(10 \%[\mathrm{v} / \mathrm{v}]\right.$ in DEPC-treated $\left.\mathrm{H}_{2} \mathrm{O}\right)$

$10 \mu \mathrm{L}$

$\operatorname{PBT}(0.5 \times)<\mathrm{R}>$

$406.67 \mu \mathrm{L}$

Final volume

$1 \mathrm{~mL}$

Prepare immediately before use.

Normal Goat Serum (NGS; 5\%)

Normal goat serum

$2.5 \mathrm{~mL}$

PBT $(0.5 \times)<$ R $>$

$47.5 \mathrm{~mL}$

Final volume

$50 \mathrm{~mL}$

Store for up to $1 \mathrm{mo}$ at $4^{\circ} \mathrm{C}$.

Phosphate-Buffered Saline (PBS; 10x, pH 7.4)

$\mathrm{Na}_{2} \mathrm{HPO}_{4} \cdot 7 \mathrm{H}_{2} \mathrm{O}$

$25.6 \mathrm{~g}$

$\mathrm{NaCl}$

$80 \mathrm{~g}$

$\mathrm{KCl}$

$\mathrm{KH}_{2} \mathrm{PO}_{4}$

$2 \mathrm{~g}$

$\mathrm{H}_{2} \mathrm{O}$

$2 \mathrm{~g}$

Final volume

$\sim 1 \mathrm{~L}$

Mix the ingredients and adjust the $\mathrm{pH}$ to 7.4. Sterilize by autoclaving. Store for up to $1 \mathrm{yr}$ at room temperature.

$\operatorname{PBT}(0.5 \times)$

Phosphate-buffered saline (PBS; 10X, pH 7.4) $<\mathrm{R}>$

$2.5 \mathrm{~mL}$

Triton X-100 $\left(10 \%[\mathrm{v} / \mathrm{v}]\right.$ in DEPC-treated $\left.\mathrm{H}_{2} \mathrm{O}\right)$

$500 \mu \mathrm{L}$

Distilled $\mathrm{H}_{2} \mathrm{O}$

$47 \mathrm{~mL}$

Final volume

$50 \mathrm{~mL}$

Store for up to $1 \mathrm{mo}$ at room temperature. 
F.W. Smith and W.N. Gabriel

ACKNOWLEDGMENTS

The protocol presented here was developed through an EDEN award National Science Foundation/ Evo-Devo-Eco Network (NSF/EDEN grant no. IOS-0955517) to F.W.S.

\section{REFERENCES}

Gabriel WN, Goldstein B. 2007. Segmental expression of Pax3/7 and Engrailed homologs in tardigrade development. Dev Genes Evol 217: 421-433.

Gross V, Mayer G. 2015. Neural development in the tardigrade Hypsibius dujardini based on anti-acetylated $\alpha$-tubulin immunolabeling. EvoDevo 6: 12.

Irvine SQ. 2007. Whole-mount in situ hybridization of small invertebrate embryos using laboratory mini-columns. Biotechniques 43: 764-768.
McNuff R. 2018. Laboratory culture of Hypsibius exemplaris. Cold Spring Harb Protoc doi:10.1101/pdb.prot102319.

Smith FW, Jockusch EL. 2014. The metameric pattern of Hypsibius dujardini (Eutardigrada) and its relationship to that of other panarthropods. Front Zool 11: 66.

Smith FW, Boothby TC, Giovannini I, Rebecchi L, Jockusch EL, Goldstein B. 2016. The compact body plan of tardigrades evolved by the loss of a large body region. Curr Biol 26: 224-229. 


\section{Embryonic Immunostaining for the Tardigrade Hypsibius exemplaris}

Frank W. Smith and Willow N. Gabriel

Cold Spring Harb Protoc; doi: 10.1101/pdb.prot102343

\begin{tabular}{rc}
$\begin{array}{r}\text { Email Alerting } \\
\text { Service }\end{array}$ & Receive free email alerts when new articles cite this article - click here. \\
\hline $\begin{array}{c}\text { Subject } \\
\text { Categories }\end{array}$ & $\begin{array}{c}\text { Browse articles on similar topics from Cold Spring Harbor Protocols. } \\
\text { Developmental Biology (728 articles) } \\
\text { Emerging Model Organisms (321 articles) } \\
\text { Imaging Development (255 articles) } \\
\text { Immunostaining (139 articles) } \\
\text { Immunostaining, general (94 articles) }\end{array}$ \\
\hline
\end{tabular}

